\title{
Categorization of extinction risk of Discocactus species
}

\author{
Anny Bianca Santos Cruz ${ }^{\mathrm{a}} \bullet$, Daniel Oliveira Reis ${ }^{\mathrm{a}}$, Juliano Ricardo Fabricante ${ }^{\mathrm{a}}$ \\ a Universidade Federal de Sergipe, Itabaiana, 49.510-200, Sergipe, Brasil. *bianca.bbb@live.com
}

Received: October 23, 2021 / Accepted: November 11, 2022 / Published online: January 31, 2022

\begin{abstract}
The present study aimed to update the categorization of the extinction risk of Discocactus bahiensis Britton \& Rose and Discocactus zehntneri Britton \& Rose, endemic Cactaceae species from Northeastern Brazil. The georeferenced species occurrence points were obtained from the online databases speciesLink and Global Biodiversity Information Facility (GBIF). Polygons were traced using these points, being gridded with $4 \mathrm{~km}^{2}$ cells and virtually divided in half $\left(2 \mathrm{~km}^{2}\right)$. Afterwards, the cells occupied by the species were counted in order to obtain their occupation areas. The species D.bahiensis presented 17 records and an occupation area of $32 \mathrm{~km}^{2}$, while D.zehntneri presented 15 records and an occupation area of $24 \mathrm{~km}^{2}$. The sites where the species are found present different factors of anthropic pressure. Thus, the species D.bahienses and D.zehntneri were categorized as "Endangered", according to the B2biiicii criteria.
\end{abstract}

Keywords: Biodiversity; Caatinga; Cactaceae; Endangered species.

\section{Categorização de risco de extinção de espécies de Discocactus}

\begin{abstract}
Resumo
O presente estudo teve como objetivo realizar a atualização da categorização do risco de extinção de DiscocactusbahiensisBritton\& Rose e DiscocactuszehntneriBritton\& Rose, espécies de Cactaceae endêmicas do Nordeste brasileiro. Os pontos de ocorrência georreferenciados das espécies foram obtidos nas bases de dados online speciesLink eGlobal Biodiversity Information Facility (GBIF). Com esses pontos foram traçados polígonos que foram gradeados com células de 4 $\mathrm{km}^{2}$ e divididas virtualmente pela metade $\left(2 \mathrm{~km}^{2}\right)$. Posteriormente foram contabilizadas as células ocupadas pelas espécies para a obtenção das áreas de ocupação das mesmas. A espécieD. bahiensis apresentou17 registros e uma área de ocupação de 32 $\mathrm{km}^{2}$, enquanto D. zehntneri apresentou 15 registros e uma área de ocupação de $24 \mathrm{~km}^{2}$. Os locais nos quais as espécies são encontradas apresentam diversos fatores de pressão antrópica. Assim, as espécies D. bahienses e D. zehntneri foram categorizadas como "Em perigo" de acordo com os critérios B2biiicii.
\end{abstract}

Palavras-chave: Biodiversidade; Caatinga; Cactaceae; Espécies ameaçadas.

\section{Introduction}

The Caatinga is heavily degraded and only $8.92 \%$ of its extension is protected by conservation units (Brasil, 2022). As a result, many species are endangered, especially rare and endemic species.

In the Caatinga, there are species of the Cactaceae family, which contribute to its landscape and visual identity. This family has approximately 484 species belonging to 81 genera (Flora do Brasil, 2020). These species present numerous adaptations, such as thorns, which are modified leaves that help to store water, so that the species can survive in the environment aforementioned (UFRB, 2020).

Among Cactaceae, there are species such as Discocactus bahiensis Britton \& Rose and Discocactus zehntneri Britton \& Rose. Both are endemic to the Caatinga and presented restricted distributions. In addition, they occur in sites under strong anthropogenic pressure (CNCFlora, 2012). Therefore, it is necessary to frequently review the categorization of extinction risk of these species.

Categorizing the extinction risk is an important tool for the conservation of taxa (Martinelli and Moraes, 2013). Based on categorization results, it is possible to direct efforts and resources towards the protection of endangered species (Mace et al., 2008).

Thus, categorizing the extinction risk of endemic species in the Caatinga is necessary for the creation of management plans that foster preservation. Therefore, this study aimed to updatethe categorization of extinction risk of Discocactus bahiensis Britton \& Rose and Discocactus zehntneri Britton $\&$ Rose, species endemic to Northeastern Brazil.

\section{Materials and Methods}

The Caatinga is a phytogeographic domain that covers seven states in the Northeastern region of Brazil and Minas 
Gerais. This domain has a semi-arid climate, with annual average rainfall of $1,000 \mathrm{~mm}$. It is also part of the global biome classified as seasonally dry tropical forests (Fernandes \& Queiroz, 2018).

This phytogeographic domain is the third most degraded in the country (ASA, 2017). These are environments that suffer from agriculture and livestock, among other activities that are levers for changing their original state of conservation (Garlet, Canto \& Oliveira, 2018).

Georeferenced species occurrence points were collected from the online database speciesLink (2021) and GBIF (2021). Duplicate and erroneous points were eliminated. The remaining coordinates were used to elaborate the polygon, following the principle of the minimum convex polygon, which was later gridded with $4 \mathrm{~km}^{2}$ cells that were virtually divided in half $\left(2 \mathrm{~km}^{2}\right)$. The process was carried out separately for each species. Cells with the proven presence of D.bahiensis and D.zehntneri were computed to obtain their occupation area (IUCN, 2019). The maps were built using the software Qgis. Finally, the sites of occurrence of the species were investigated in order to identify elements of anthropic pressure that could make it impossible for them to remain in these areas.

\section{Results and Discussion}

The occupation areas obtained for D.bahiensis and D.zehntneri were $32 \mathrm{~km}^{2}$ (17 records) and $24 \mathrm{~km}^{2}$ (15 records), respectively (Figure 1). These results, in association with the conservation conditions of the sites where these species occur, qualify both species as "Endangered", according to the B2biiiicii criteria.
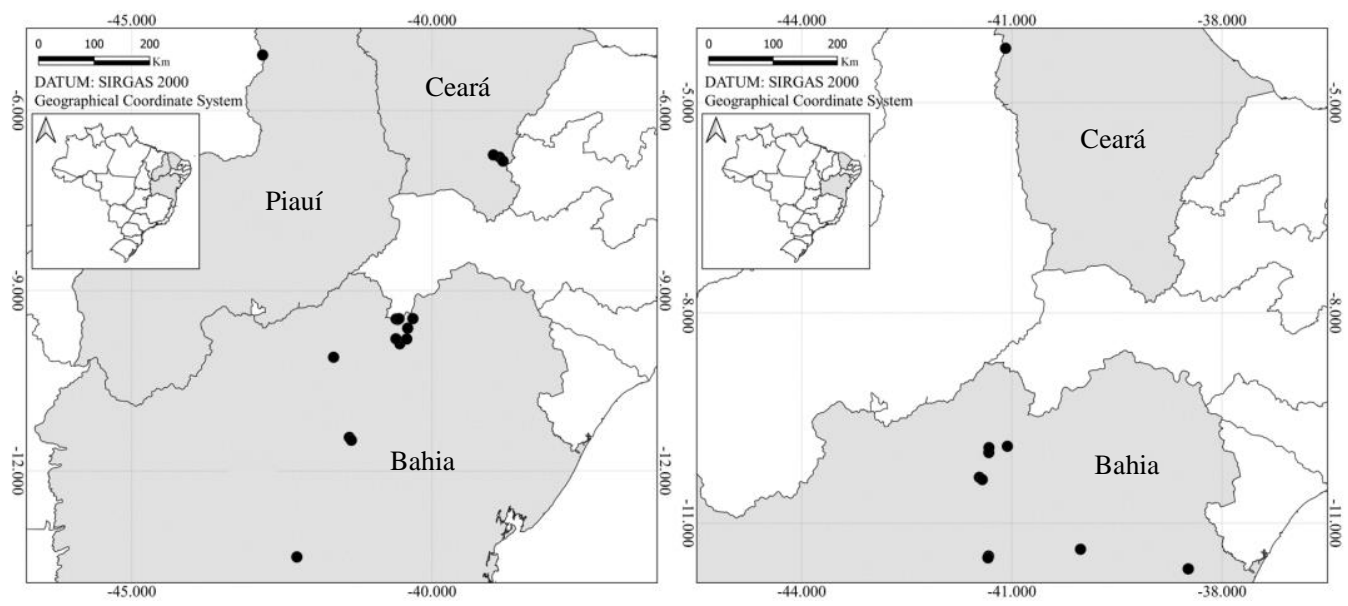

Figure 1. Distribution map of the occurrence points of the species Discocactus bahiensis Britton \& Rose (A) and Discocactus zehntneri Britton \& Rose (B), found in the Northeastern region of Brazil and being distributed in the states of Bahia, Ceará and Piauí, in the Caatinga biome.

According to CNCFlora, in 2012 the species D. bahiensis and D. zehntneri were categorized as "Vulnerable". The species D. bahiensis occurs exclusively in sites of the Caatinga in the states of Bahia, Piauí, and Ceará. On the other hand, D. zehntneri only occurs in Bahia and Ceará.

Additionally, it is possible to observe a considerable reduction in natural areas between 2012 and 2020 in some of the sites where D. bahiensis (Figure 2) and D. zehntneri (Figure 3) occur.

The conservation conditions of the Caatinga in these three states are quite similar. Extensive agriculture and livestock (Alves, Araújo, \& Nascimento, 2009), selective logging (Souza, Costa, Alencar, \& Lima, 2018), fires (Alves et al., 2009), and illegal plant extraction (Souza et al., 2018) are the worst current threats.

Some of the available records of the species addressed in this study were collected in periods that precede the evaluation by the MapBiomas. Thus, it is possible that part or even entire populations of both species have been excluded from the areas presented due to degradation over the years. It is advisable to carry out expeditions in order to evaluate the current state of these populations.
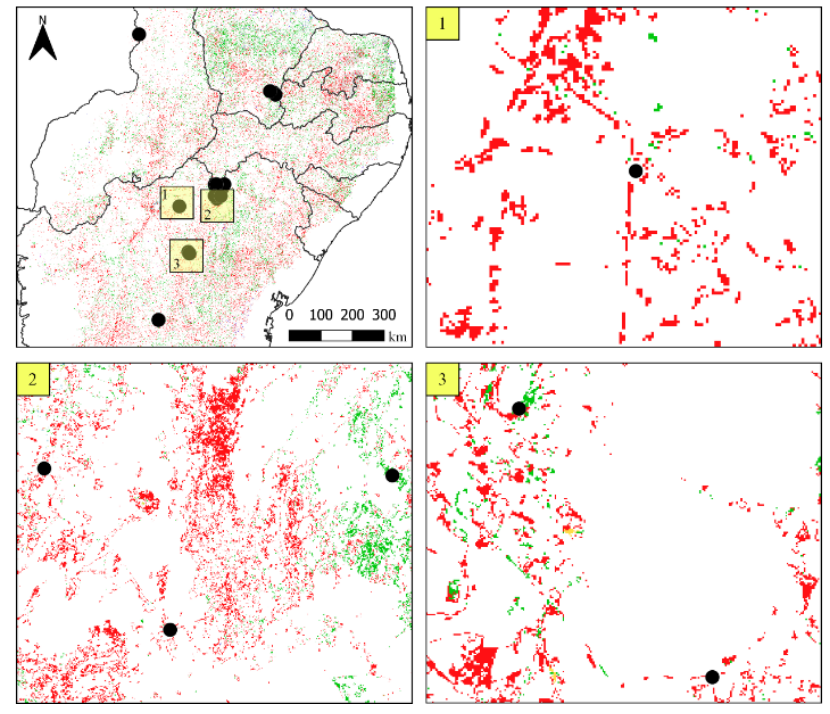

Figure 2. Map of the reduction (red color) and increase (green) of natural areas and forests, between 2012 and 2020, in the region of occurrence of Discocactus bahiensis Britton $\&$ Rose (black points). Source: MapBiomas. 

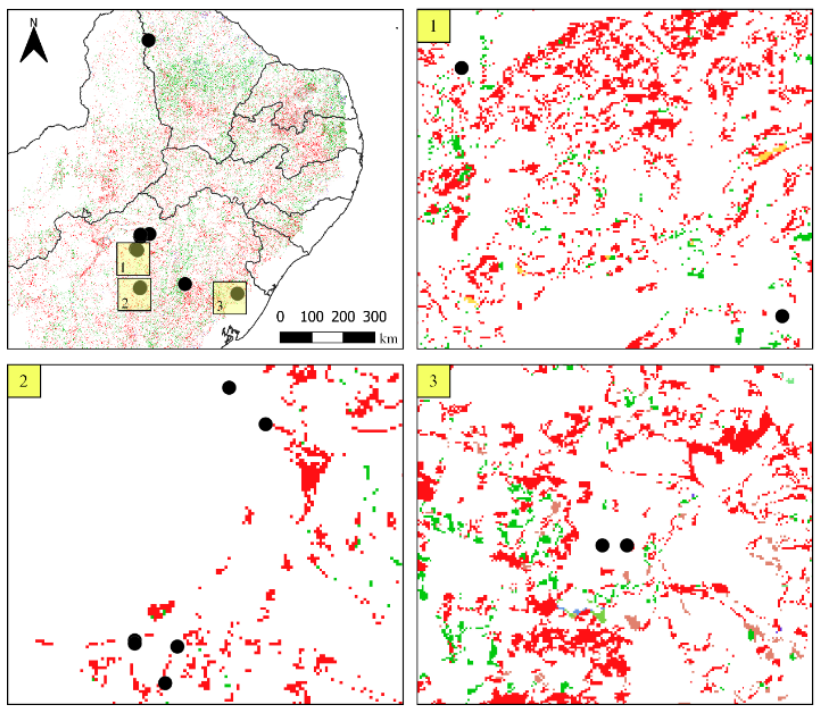

Figure 3. Map of the reduction (red color) and increase (green) of natural areas and forests, between 2012 and 2020, in the region of occurrence of Discocactus zehntneri Britton \& Rose (black point). Source: MapBiomas.

Furthermore, although the populations have not been directly affected by the degradation process, the areas presented may have been impacted due to changes in the environment caused by fragmentation. Fragmentation can increase the probability of local extinctions of species whose population is small or restricted, reducing their size (Primack \& Rodrigues, 2001; Ricklefs \& Relyea, 2016).

It is important to emphasize that projections indicate that the climate changes expected for the coming years may be harmful to Caatinga species (Santos, et al., 2014; Silva et al., 2019). Some scenarios suggest an increase in water deficit, aridity, and temperature, in addition to a reduction in precipitation (Marengo, Torres, \& Alves, 2017; Tabarelli, Scarano, \& Silva, 2017). These changes may generate additional problems for the conservation of the site where the studied species occur.

Thus, measures can be taken to preserve and conserve these species, such as management plans created by public policies that help in the conservation and sustainable use of the environment where the species are inserted. Thus, anthropic actions in the region would be prohibited. In addition, ex situ conservation actions can also help to maintain species in botanical gardens and seed banks.

\section{Conclusion}

The species Discocactus bahiensis and Discocactus zehntneri are at high risk of extinction. Thus, we suggest the creation of public policies that aim at the conservation of the sites where these species occur, as well as actions aimed at their ex situ conservation.

\section{References}

Alves, J. J. A., Araújo, M. A., \& Nascimento, S. S. (2009). Degradação da Caatinga: uma investigação ecogeográfica. Revista Caatinga, 22(3), 126135 .
Articulação Semiárido Brasileiro -ASA. (2017). Semiarido - É no semiarido que a vida pulsa. Retrieved January 31, 2022.

Brasil. 2022. Cadastro Nacional de Unidades de Conservação. Retrieved January $31,2022$.

CNCFlora. 2012. Discocactus bahiensis in Lista Vermelha da flora brasileira. versão 2012.2 Centro Nacional de Conservação da Flora. Retrieved January 31, 2022.

CNCFlora. 2012. Discocactus zehntneri in Lista Vermelha da flora brasileira versão 2012.2 Centro Nacional de Conservação da Flora. Retrieved January 31, 2022.

Fernandes, M. F., \& Queiroz, L. P.(2018). Vegetação e flora da Caatinga. Ciência e cultura,70(4), 51-56. doi: 10.21800/231766602018000400014

FLORA DO BRASIL 2020. 2021. <http://floradobrasil.jbrj.gov.br/>.

Garlet, A., Canto, J. L. D., \& Oliveira, P. R. S. D. O manejo florestal comunitário da caatinga em assentamentos rurais no estado da Paraíba. Ciência Florestal, 28, 735-745. 2018. doi: 10.5902/1980509832086

GBIF. 2021. <https://www.gbif.org/>.

IUCN. 2019. Guidelines for Using the IUCN Red List Categories and Criteria. 〈http://cmsdocs.s3.amazonaws.com/RedListGuidelines.pdf >.

Mace, G. M., Collar, N. J., Gaston, K. J., Hilton-Taylor, C. R. A. I. G., Akçakaya, H. R., Leader-Williams, N.I.G.E.L.,Milner-Gulland, E.J., \& Stuart, S.N. (2008). Quantification of extinction risk: IUCN's system for classifying threatened species. Conservation biology, 22(6), 14241442. doi: $10.1111 / j .1523-1739.2008 .01044 . x$

Marengo, J. A., Torres, R. R., \& Alves, L. M. (2017). Drought in Northeast Brazil - past, present, and future. Theoretical and Applied Climatology, 129(3), 1189-1200. doi: 10.1007/s00704-016-1840-8

Martinelli, G., \&Moraes, M. A. (2013). Livro vermelho da flora do Brasil. $\left(1^{\text {a }}\right.$ ed.). Rio de Janeiro: CIP Brasil. http://dspace.jbrj.gov.br/jspui/handle/doc/26

Primack, R. B., \& Rodrigues, E. (2001). Biologia da Conservação. ( $8^{\mathrm{a}}$ ed.). Londrina: Planta.

Ricklefs, R., \& Relyea, R. (2016). A economia da natureza. (7a ed.). Rio de Janeiro: Guanabara Koogan.

Santos, M. G., Oliveira, M. T., Figueiredo, K. V., Falcao, H. M., Arruda, E. C., Almeida-Cortez, J., Sampaio E., Ometto J., Menezes R., Oliveira A., Pompelli M., \& Antonio, A. (2014). Caatinga, the Brazilian dry tropical forest: can it tolerate climate changes? Theoretical and Experimental Plant Physiology, 26(1), 83-99. doi: 10.1007/s40626014-0008-0

Silva, J. L. S. E., Cruz-Neto, O., Peres, C. A., Tabarelli, M., \& Lopes, A. V. (2019). Climate change will reduce suitable Caatinga dry forest habitat for endemic plants with disproportionate impacts on specialized reproductive strategies. PloSone, 14(5), e0217028. doi: 10.1371/journal.pone.0217028

Souza, A. P., Costa, F. C. P., Alencar, R. F., \& Lima, S. F. B. (2018). Exploração e utilização do potencial madeireiro da Caatinga no município de Aurora-estado do Ceará. Pesquisa e Ensino em Ciências Exatas e da Natureza, 2(2), 158-168. doi: 10.29215/pecen.v2i2.1070

Specieslink. 2021. <http://www.splink.org.br/>.

Tabarelli, M., Leal, I. R., Scarano, F. R., \& Silva, J. M. C. (2017). The future of the Caatinga. In: J. M. C. Silva, I. R. Leal, \& M. Tabarelli (Eds.). Caatinga: The Largest Tropical Dry Forest Region in South America. ( $1^{\text {a }}$ ed., cap. 19, p. 461-474), Cham: Springer. doi: /10.1007/978-3-31968339-3_19

UFRB. 2020. Curso de Fisiologia Vegetal. Org. Peixoto, C.P, et al. 218p.

\section{License: Creative Commons CC Y 4.0}

This article was published with open access for distribution under the terms of the Creative Commons Attribution License, which allows unrestricted use, distribution, and reproduction in any medium, provided the original work is properly cited. 